\title{
Comparative Effectiveness of Fipronil and Other Insecticide Treatments against Cotton Leafworm and Role of Two Detoxification Enzymes
}

\author{
Hamdy K. Abou-Taleb ${ }^{1 *}$, Ahmed A. Barrania ${ }^{2}$ and Manal A. Attia ${ }^{3}$
}

\begin{abstract}
Field studies were conducted in two different locations at El-Behira Governorate, in 2013 and 2014 cotton seasons to evaluate some insecticide treatments against cotton leafworm (CLW), Spodoptera littoralis (Boisd.). Glutathione $S$-transferase (GST) and esterases activities in the CLW larvae from the two locations were compared. Spinetoram (field rate (FR)) / lufenuron (0.5 FR) mixture achieved the highest \%reduction of CLW larvae, followed by fipronil (FR) / lufenuron (0.5 FR) mixture which are followed by spinetoram (FR) and fipronil (FR). At AbouEImatameer, spinetoram / lufenuron mixture achived CLW \%reduction of $90.3,92.5,91.5,89.8$ and $86.5 \%$ in 2013 and $90.8,94.5,90.3,85.8$ and $83.0 \%$ in 2014 season after 1-, 3-, 5-, 7- and 10-days of treatment, respectively. The same mixture reduced CLW larvae numbers by 91.3 , 91.0, 89.0 85.8 and 83.3\%, in 2013 and 91.0, 92.0, 91.0 90.3 and $88.3 \%$ in 2014 after 1-, 3-, 5-, 7- and 10-days of treatment, respectively, at Shobrakeate. On the other hand, cypermethrin and chlorpyrifos treatments achieved the least \%reduction of CLW larvae. Mixing the 0.5 FR of lufenuron with the tested insecticides (chlorpyrifos, cypermethrin, fipronil and spinetoram) resulted in increasing their efficacy against CLW. Statistically, field performance of cypermethrin, chlorpyrifos and cypermethrin / lufenuron (0.5 FR) mixture were higher at Shobrakeate than at AbouElmatameer in both seasons 2013 and 2014, where other insecticide treatments were comparable. AbouElmatameer CLW strain showed significantly higher esterases and GST activities about 2fold compared with that of Shobrakeate one in both seasons. From these results, fipronil and spinetoram can be good alternatives and can be used alone or in a combination with lufenuron to improve the CLW control and overcome the insecticide resistance.
\end{abstract}

Keywords: Cotton leafworm, Fipronil, Spinetoram, Esterases, GST.

\section{INTRODUCTION}

The cotton leafworm (CLW), Spodoptera littoralis, is one of the most destructive agricultural lepidopterous pests. It can attack numerous economically important crops all the year round. On cotton, the pest may cause considerable damage by feeding on the leaves, fruiting points, flower buds and, occasionally, also on bolls. The chemical control of CLW has been extensively reported in relation especially to cotton in Egypt (Issa et al., 1984a \& b and Abo-El-Ghar et al., 1986). Extensive use of insecticides, multiple generations of CLW per annum, and the availability of host crops, around the year, have contributed to the development of resistance in this pest to many insecticide groups (Abo-Elghar et al., 2005; Abou-Taleb, 2010). Therefore, searching for an effective alternatives and/or pest control strategies to avoid increasing selection pressure of the insect population to insecticides becomes so important, to provide adequate crop protection for sustainable food, feed and fiber production. This need is met in part by fipronil, the first phenylpyrazole introduced for pest control (Moffat, 1993). Fipronil is effective, at low field application rates, against insects that are resistant to pyrethroids, organophosphates and carbamate insecticides (Bobe et al., 1997). Also, insecticide mixtures are one of the adopted strategies to overcome the problem of resistance (Ahmad et al., 2008).

Fipronil mode of action does not follow the common biochemical pathways of the classical insecticides (pyrethroids, organophosphates, and carbamates) that many insects have developed resistance to them (Aajoud et al., 2003). Cole et al. (1993) found that fipronil interferes with the GABA-gated channels; fipronil disrupts normal nerve influx transmission (e.g., passage of chloride ions) by targeting the GABA-gated chloride channel and at sufficient doses, causes excessive neural excitation, severe paralysis, and insect death (Aajoud et al., 2003; Gant et al., 1998). Fipronil demonstrates a selective toxicity toward insects by having a tighter binding affinity toward the GABAregulated chloride channels of insects than the mammalian GABA receptors (Hainzl and Casida, 1996).

Theoretically, under certain conditions, mixtures can delay the development of resistance more effectively than sequences or rotations (Roush, 1993) because, if resistance to each compound is independent and initially rare, the associated probability of resistance to both compounds is then extremely rare (Curtis, 1985).

\footnotetext{
${ }^{1}$ Plant Protection Research Institute, ARC, Bacous, Sabahia, Alexandria Egypt.

*aboutalebhk@yahoo.com

${ }^{2}$ Plant Protection Research Institute, Etay El-baroud Agric. Res. Station. Agric. Res. Center, Egypt.

${ }^{3}$ Central Pesticides Laboratory, Sabahia Station, Alexandria Egypt.

Received November 15, 2015, Accepted December 7, 2015
} 
Therefore, our objective was to compare among the field performances of fipronil, spinetoram, chlorpyrifos and cypermethrin in two locations in El-Behira governorate against CLW with reference to glutathione $S$-transferase and esterases activities. The mixtures of these insecticides with $0.5 \mathrm{FR}$ of the IGR, lufenuron were also evaluated. Such studies could help to improve the pest control and to formulate a strategy to minimize the development of CLW resistance to insecticides.

\section{MATERIALS AND METHODS}

\section{Insecticides:}

Fipronil (Rado- $\mathrm{X}^{\circledR} 80 \% \mathrm{WG}$ ), was produced by Jiangsu Tuoqiu Agrochemical Co. Spinetoram (Radiant $^{\circledR} \quad 12 \% \mathrm{SC}$ ) and chlorpyrifos (Dursban ${ }^{\circledR} \quad 48 \%$ EC) were produced by Dow Agrosciences Co. Alphacypermethrin (Alpha-cypermethrin ${ }^{\circledR} \quad 10 \%$ EC) was produced by Tagros Chemicals India Limited. Lufenuron (Match ${ }^{\circledR} 5 \%$ EC) was produced by Syngenta.

\section{Field trials and the experimental design:}

Field trials were conducted during two cotton seasons 2013 and 2014 at two different cities, AbouElmatameer and Shobrakeate on El-Behira Governorate. Cotton variety Giza 86 was cultivated at May 3 and 5 during 2013 season and May 6 and 9, during 2014 season, for the AbouElmatameer and Shoubrakeate experiments, respectively. All cultural practices were carried out according to "good agricultural practice". Treatments were fipronil (40 gm / fed.), chlorpyrifos (1 liter / fed.), spinetoram (100 ml / fed.), cypermethrin $(250 \mathrm{ml} / \mathrm{fed}$.) and the mixture of each of these insecticides with the half field rate of lufenuron (125 $\mathrm{ml} /$ fed.). All treatments in addition to control were arranged in a randomized complete block design with four replicates $\left(84 \mathrm{~m}^{2} /\right.$ each). Plots have been separated from each by unplanted rows. Insecticide applications were carried out using Knapsack sprayer equipment (CP3) at the rate of 250 liter per fed. Spraying took place on July 27 and 29, during 2013, and July 30 and August 1, during 2014 for the AbouElmatameer and Shobrakeate experiments, respectively.

The efficiency of the tested insecticides against cotton leafworm was determined by counting all insect larval instars on ten labeled plants per plot according to insecticide evaluation protocol (2013), described by Egyptian Ministry of Agriculture. Pre-treatment counts were done just before application while post-treatment counts were made on days 1, 3, 5, 7 and 10 after treatment. Reduction percentages were calculated according to Henderson and Tilton equation (1955).
Assay of esterases and GST activity in the AbouElmatameer and Shobrakeate CLW strains: Fourth and fifth instars CLW larvae were collected from AbouElmatameer and Shobrakeate cotton fields. Larvae were dissected; midguts collected and rinsed in ice-cold $100 \mathrm{mM}$ phosphate buffer $\mathrm{pH} 7$ and homogenized in glass homogenizer $(1: 10 \mathrm{w} / \mathrm{v})$ in the same buffer. The homogenate was centrifuged at $15,000 \mathrm{rpm}$ for $30 \mathrm{~min}$ at $4^{\circ} \mathrm{C}$ using Cryofuge $20-3$, Heraeus Christ centrifuge. The supernatant was served as the enzymes source.

Esterase activity was determined using $\alpha$-naphthyl acetate as a substrate according to the assay method described by Van Asperen (1962). Reaction mixture with a total volume of $900 \mu \mathrm{l}$ contained: $865 \mu \mathrm{l}$ solution of $1.55 \mathrm{mM}$ fast blue RR salt and $100 \mathrm{mM}$ sodium phosphate buffer ( $\mathrm{pH} 7.6$ ), $30 \mu$ l of enzyme source and $5 \mu \mathrm{l}$ of $90 \mathrm{mM} \alpha$-naphthyl acetate in ethanol. The reaction mixture was vortexed and changes in absorption at $450 \mathrm{~nm}$ were monitored on SequoiaTurner Model 340 spectrophotometer for up to 5 minutes. An assay mixture without enzyme was used as a blank. Enzyme activity was calculated as $\Delta \mathrm{OD} \mathrm{min}^{-1}$ mg protein $^{-1}$.

Glutathione $S$-transferase was determined by using 1-chloro, 2,4-dinitrobenzen (CDNB) as a substrate (Kao et al., 1989). The assay mixture consisted of $50 \mathrm{mM}$ CDNB in $95 \%$ ethanol, $50 \mathrm{mM} \mathrm{GSH}$ and $20 \mu \mathrm{l}$ of enzyme source in $3 \mathrm{ml}$ of $50 \mathrm{mM}$ phosphate buffer $(\mathrm{pH}$ 7.5). Changes in absorbance were measured at $340 \mathrm{~nm}$ for up to $3 \mathrm{~min}$ and the enzyme activity in terms of $\mu \mathrm{mol}$ of CDNB conjugated $\mathrm{min}^{-1} \mathrm{mg}$ of enzyme protein ${ }^{-}$ ${ }^{1}$ was calculated using the extinction coefficient of 9.6 $\mathrm{mM}^{-1} \mathrm{~cm}^{-1}$. Protein concentration was measured according to (Lowry et al., 1951) using bovine serum albumin (BSA) as a standard.

\section{Statistical analysis:}

Treatments were compared for significance at 0.05 using LSD test (SAS, 1999).

\section{RESULTS}

Field efficiency of tested insecticide treatments against cotton leafworm:

Reduction percentages of cotton leafworm larvae after different times of insecticides application at AbouElmatameer and Shobrakeate, 2013 and 2014 cotton seasons are presented in Tables (1, 2, 3 and 4). Results revealed that, spinetoram (FR) / lufenuron $(0.5$ FR) mixture achieved the highest \%reduction of CLW larvae, followed by fipronil (FR) / lufenuron (0.5 FR) mixture which are followed by spinetoram alone and fipronil alone. Percent reduction of CLW larvae were 90.3, 92.5, 91.5, 89.8 and $86.5 \%$ in 2013 and $90.8,94.5$, $90.3,85.8$ and $83.0 \%$ in 2014 season after 1-, 3-, 5-, 7- 
and 10-days of treatment by spinetoram/lufenuron mixture, respectively, at AbouElmatameer (Tables 1 and 2). At Shobrakeate, spinetoram/lufenuron mixture reduced CLW larvae numbers by $91.3,91.0,89.085 .8$ and $83.3 \%$, in 2013 and $91.0,92.0,91.090 .3$ and $88.3 \%$ in 2014 after 1-, 3-, 5-, 7- and 10-days of treatment, respectively (Tables 3 and 4). On the other hand, cypermethrin and chlorpyrifos treatments achieved the least \%reduction of CLW larvae. At AbouElmatameer, cypermethrin achieved CLW larvae reduction of 68.5, $70.8,72.3,68.0$ and $66.8 \%$, in 2013 and $68.5,70.3$, $70.3,68.5$ and $67.5 \%$ in 2014 after 1-, 3-, 5-, 7- and 10days of treatment, respectively (Tables 1 and 2). In case of Shobrakeate, cypermethrin reduced number of CLW larvae by $80.5,79.5,77.8,75.5$ and $72.3 \%$, in 2013 and 79.0, 78.8, 77.8, 75.8 and 75.0\% in 2014 after 1-, 3-, 5-, 7- and 10-days of treatment, respectively (Tables 3 and 4).

Results in Tables (1, 2, 3 and 4) clarified that, mixing the half field rate of lufenuron with tested insecticides resulted in increasing their efficacy. At AbouElmatameer in 2013, reduction percentage of CLW larvae was increased from 68.5, 70.8, 72.3, 68.0 and $66.8 \%$ when cypermethrin alone was used to 80.0 , $81.8,82.077 .5$ and $74.3 \%$ when cypermethrin was mixed with the half field rate of lufenuron after 1-, 3-, 5-, 7- and 10-days of treatment, respectively (Table 1). At Shobrakeate in 2013, reduction percentage of CLW larvae was increased from 80.5, 79.5, 77.8, 75.5 and $72.3 \%$ when cypermethrin alone was used to $84.8,85.8$, 82.578 .5 and $75.0 \%$ when cypermethrin was mixed with the half field rate of lufenuron after 1-, 3-, 5-, 7and 10-days of treatment, respectively (Table 3). The same trend of results was repeated at AbouElmatameer and Shobrakeate in 2014. Results with the same trend were obtained with fipronil, chlorpyrifos and spinetoram at AbouElmatameer and Shobrakeate in 2013 and 2014.

Comparison between field performance of the insecticide treatments against CLW larvae at
AbouElmatameer and Shobrakeate in 2013 and 2014 were presented in Figures (1 and 2). According to the statistical analysis, field performance of cypermethrin, chlorpyrifos and cypermethrin / lufenuron (half field rate) mixture were higher at Shobrakeate compared to at AbouElmatameer in both cotton seasons 2013 and 2014. Averages of CLW reduction \% caused by all other insecticide treatments were statistically comparable at AbouElmatameer and Shobrakeate in seasons 2013 and 2014. While, cypermethrin recorded an average of CLW larvae reduction $69.3 \%$ at AbouElmatameer, it recorded $77.1 \%$ average reduction of CLW larvae at Shobrakeate, in 2013. With regard to chlorpyrifos, average reduction $\%$ of CLW $73.5 \%$ at AbouElmatameer, however it was $78.6 \%$ at Shobrakeate, in 2013 (Figure 1). Average of CLW reduction $\%$ caused by cypermethrin in 2014 was increased from $69.0 \%$ at AbouElmatameer to $77.3 \%$ at Shobrakeate. Also, average of CLW reduction $\%$ caused by chlorpyrifos was increased from $72.7 \%$ at AbouElmatameer to $77.8 \%$ at Shobrakeate in 2014 (Figure 2).

Activity of esterases and GST in the AbouElmatameer and Shobrakeate CLW strains:

The increase in esterases activity was significant in the AbouElmatameer CLW strain than Shobrakeate CLW strains. Esterases activity in the AbouElmatameer CLW strain (0.38 and $0.49 \Delta \mathrm{OD} / \mathrm{mg}$ protein / min) was 2.0 and 2.05 times the esterases activity in the Shobrakeate CLW strain (0.19 and $0.24 \Delta$ OD / mg protein / $\mathrm{min}$ ) in 2013 and 2014, respectively, (Table 5). AbouElmatameer CLW strain showed significantly more GST activity, 2.00 and 1.94-fold in 2013 and 2014 compared with that of Shobrakeate CLW strain. While, GST activity was 138.3 and $160.4 \mu \mathrm{mol} / \mathrm{mg}$ protein / $\min$ in 2013 and 2014, respectively at AbouElmatameer, it was 69.4 and $82.6 \mu \mathrm{mol} / \mathrm{mg}$ protein / $\min$ in 2013 and 2014, respectively at Shobrakeate.

Table 1. \% Reduction of cotton leafworm larvae after different times of insecticides treatments at AbouEImatameer 2013

\begin{tabular}{lccccc}
\hline \multirow{2}{*}{ Treatments } & \multicolumn{5}{c}{ \% Reduction } \\
\cline { 2 - 6 } & 1-day & 3-days & 5-days & 7-days & 10-days \\
\hline Fipronil & $80.5 \pm 1.8 \mathrm{c}$ & $85.8 \pm 1.3 \mathrm{~b}$ & $88.4 \pm 1.0 \mathrm{c}$ & $83.8 \pm 1.1 \mathrm{c}$ & $81.5 \pm 1.7 \mathrm{~b}$ \\
Chlorpyrifos & $72.3 \pm 1.5 \mathrm{~d}$ & $74.5 \pm 0.5 \mathrm{~d}$ & $76.0 \pm 0.7 \mathrm{e}$ & $73.0 \pm 1.9 \mathrm{e}$ & $71.5 \pm 2.1 \mathrm{~d}$ \\
Spinetoram & $83.0 \pm 1.6 \mathrm{c}$ & $87.5 \pm 1.1 \mathrm{~b}$ & $89.3 \pm 0.9 \mathrm{c}$ & $85.8 \pm 1.5 \mathrm{bc}$ & $83.0 \pm 1.2 \mathrm{~b}$ \\
Cypermethrin & $68.5 \pm 1.8 \mathrm{e}$ & $70.8 \pm 2.4 \mathrm{e}$ & $72.3 \pm 2.3 \mathrm{f}$ & $68.0 \pm 1.6 \mathrm{f}$ & $66.8 \pm 1.3 \mathrm{e}$ \\
Fipronil/lufenuron & $86.3 \pm 1.5 \mathrm{~b}$ & $91.8 \pm 1.3 \mathrm{a}$ & $91.8 \pm 1.5 \mathrm{a}$ & $86.5 \pm 1.1 \mathrm{~b}$ & $83.5 \pm 1.1 \mathrm{~b}$ \\
Chlorpyrifos/lufenuron & $80.3 \pm 2.2 \mathrm{c}$ & $82.8 \pm 1.9 \mathrm{c}$ & $83.5 \pm 1.5 \mathrm{~d}$ & $79.0 \pm 1.9 \mathrm{~d}$ & $75.3 \pm 0.8 \mathrm{c}$ \\
Spinetoram/lufenuron & $90.3 \pm 1.5 \mathrm{a}$ & $92.5 \pm 0.9 \mathrm{a}$ & $91.5 \pm 1.5 \mathrm{a}$ & $89.8 \pm 1.1 \mathrm{a}$ & $86.5 \pm 2.1 \mathrm{a}$ \\
Cypermethrin/lufenuron & $80.8 \pm 1.5 \mathrm{c}$ & $81.8 \pm 0.8 \mathrm{c}$ & $82.0 \pm 1.6 \mathrm{~d}$ & $77.5 \pm 1.1 \mathrm{~d}$ & $74.3 \pm 1.8 \mathrm{c}$ \\
\hline
\end{tabular}

${ }^{*}$ Lufenuron was used at the half field rate. Numbers within the same column with a letter in common are not significantly different according to analysis of variance (ANOVA) test (LSD at $\mathrm{P}<0.05$ ). 
Table 2. \% Reduction of cotton leafworm larvae after different times of insecticides treatments at AbouEImatameer 2014

\begin{tabular}{lccccc}
\hline \multicolumn{1}{c}{ +Treatments } & \multicolumn{5}{c}{ \% Reduction } \\
\cline { 2 - 6 } & \multicolumn{1}{c}{ 1-day } & 3-days & 5-days & 7-days & 10-days \\
\hline Fipronil & $81.8 \pm 1.5 \mathrm{c}$ & $87.8 \pm 1.5 \mathrm{c}$ & $90.8 \pm 1.8 \mathrm{a}$ & $85.8 \pm 1.1 \mathrm{a}$ & $81.5 \pm 1.5 \mathrm{a}$ \\
Chlorpyrifos & $72.0 \pm 2.2 \mathrm{~d}$ & $72.8 \pm 2.2 \mathrm{e}$ & $74.8 \pm 1.9 \mathrm{c}$ & $72.8 \pm 1.8 \mathrm{c}$ & $71.0 \pm 2.7 \mathrm{c}$ \\
Spinetoram & $84.3 \pm 1.1 \mathrm{bc}$ & $91.0 \pm 1.9 \mathrm{~b}$ & $89.8 \pm 1.1 \mathrm{a}$ & $84.0 \pm 1.2 \mathrm{a}$ & $81.8 \pm 2.3 \mathrm{a}$ \\
Cypermethrin & $68.5 \pm 1.8 \mathrm{e}$ & $70.3 \pm 1.5 \mathrm{e}$ & $70.3 \pm 2.5 \mathrm{~d}$ & $68.5 \pm 1.8 \mathrm{~d}$ & $67.5 \pm 1.1 \mathrm{~d}$ \\
Fipronil/lufenuron & $87.0 \pm 1.6 \mathrm{~b}$ & $92.0 \pm 1.9 \mathrm{ab}$ & $89.8 \pm 1.8 \mathrm{a}$ & $85.5 \pm 1.1 \mathrm{a}$ & $83.0 \pm 1.9 \mathrm{a}$ \\
Chlorpyrifos/lufenuron & $82.3 \pm 1.5 \mathrm{c}$ & $83.8 \pm 1.8 \mathrm{~d}$ & $80.5 \pm 2.5 \mathrm{~b}$ & $78.0 \pm 1.6 \mathrm{~b}$ & $76.8 \pm 1.6 \mathrm{~b}$ \\
Spinetoram/lufenuron & $90.8 \pm 1.1 \mathrm{a}$ & $94.5 \pm 2.1 \mathrm{a}$ & $90.3 \pm 2.3 \mathrm{a}$ & $85.8 \pm 1.1 \mathrm{a}$ & $83.0 \pm 1.8 \mathrm{a}$ \\
Cypermethrin/lufenuron & $81.5 \pm 2.3 \mathrm{c}$ & $82.3 \pm 2.2 \mathrm{~d}$ & $74.0 \pm 1.4 \mathrm{c}$ & $72.5 \pm 1.5 \mathrm{c}$ & $69.8 \pm 1.5 \mathrm{~cd}$ \\
\hline
\end{tabular}

${ }^{*}$ Lufenuron was used at the half field rate. Numbers within the same column with a letter in common are not significantly different according to analysis of variance (ANOVA) test (LSD at $\mathrm{P}<0.05)$.

Table 3. \%Reduction of cotton leafworm larvae after different times of insecticides treatments at Shobrakeate 2013

\begin{tabular}{lccccc}
\hline Treatments & \multicolumn{5}{c}{ \% Reduction } \\
\cline { 2 - 6 } & 1-day & 3-days & 5-days & 7-days & 10-days \\
\hline Fipronil & $82.0 \pm 1.4 \mathrm{e}$ & $87.3 \pm 2.7 \mathrm{~cd}$ & $87.5 \pm 2.3 \mathrm{ab}$ & $82.8 \pm 2.4 \mathrm{bc}$ & $82.5 \pm 1.8 \mathrm{a}$ \\
Chlorpyrifos & $81.0 \pm 1.9 \mathrm{e}$ & $81.3 \pm 1.6 \mathrm{e}$ & $81.3 \pm 1.1 \mathrm{~d}$ & $75.3 \pm 1.1 \mathrm{e}$ & $74.0 \pm 1.7 \mathrm{bc}$ \\
Spinetoram & $83.8 \pm 1.1 \mathrm{~cd}$ & $87.8 \pm 1.9 \mathrm{~cd}$ & $86.0 \pm 1.6 \mathrm{bc}$ & $84.8 \pm 1.3 \mathrm{ab}$ & $81.8 \pm 1.5 \mathrm{a}$ \\
Cypermethrin & $80.5 \pm 1.1 \mathrm{e}$ & $79.5 \pm 1.1 \mathrm{e}$ & $77.8 \pm 2.2 \mathrm{e}$ & $75.5 \pm 1.7 \mathrm{e}$ & $72.3 \pm 1.5 \mathrm{c}$ \\
Fipronil/lufenuron & $86.8 \pm 1.3 \mathrm{~b}$ & $89.3 \pm 1.9 \mathrm{bc}$ & $88.5 \pm 2.3 \mathrm{ab}$ & $85.3 \pm 1.9 \mathrm{ab}$ & $83.3 \pm 2.2 \mathrm{a}$ \\
Chlorpyrifos/lufenuron & $84.5 \pm 1.8 \mathrm{bcd}$ & $86.3 \pm 1.8 \mathrm{~cd}$ & $83.5 \pm 1.1 \mathrm{~cd}$ & $80.8 \pm 1.8 \mathrm{~cd}$ & $75.5 \pm 1.7 \mathrm{~b}$ \\
Spinetoram/lufenuron & $91.3 \pm 1.9 \mathrm{a}$ & $91.0 \pm 1.6 \mathrm{a}$ & $89.0 \pm 1.6 \mathrm{a}$ & $85.8 \pm 2.8 \mathrm{a}$ & $83.3 \pm 1.9 \mathrm{a}$ \\
Cypermethrin/lufenuron & $84.8 \pm 1.3 \mathrm{bc}$ & $85.8 \pm 1.1 \mathrm{~d}$ & $82.5 \pm 1.5 \mathrm{~d}$ & $78.5 \pm 1.5 \mathrm{~d}$ & $75.0 \pm 1.7 \mathrm{~b}$ \\
\hline
\end{tabular}

${ }^{*}$ Lufenuron was used at the half field rate. Numbers within the same column with a letter in common are not significantly different according to analysis of variance (ANOVA) test (LSD at $\mathrm{P}<0.05)$.

Table 4. \%Reduction of cotton leafworm larvae after different times of insecticides treatments at Shobrakeate 2014

\begin{tabular}{lccccc}
\hline Treatments & \multicolumn{5}{c}{ \% Reduction } \\
\cline { 2 - 6 } & 1-day & 3-days & 5-days & 7-days & 10-days \\
\hline Fipronil & $80.5 \pm 1.8 \mathrm{~cd}$ & $86.5 \pm 1.1 \mathrm{~cd}$ & $90.0 \pm 1.4 \mathrm{a}$ & $85.8 \pm 2.0 \mathrm{~b}$ & $81.8 \pm 2.0 \mathrm{bc}$ \\
Chlorpyrifos & $79.0 \pm 1.6 \mathrm{~d}$ & $79.8 \pm 1.9 \mathrm{e}$ & $78.0 \pm 1.9 \mathrm{~d}$ & $77.5 \pm 2.7 \mathrm{~cd}$ & $74.8 \pm 2.2 \mathrm{e}$ \\
Spinetoram & $82.0 \pm 1.6 \mathrm{~cd}$ & $87.5 \pm 2.3 \mathrm{bc}$ & $86.0 \pm 1.7 \mathrm{~b}$ & $85.8 \pm 1.5 \mathrm{~b}$ & $83.3 \pm 1.8 \mathrm{~b}$ \\
Cypermethrin & $79.0 \pm 1.9 \mathrm{~d}$ & $78.8 \pm 1.5 \mathrm{e}$ & $77.8 \pm 1.8 \mathrm{~d}$ & $75.8 \pm 1.8 \mathrm{~d}$ & $75.0 \pm 1.4 \mathrm{e}$ \\
Fipronil/lufenuron ${ }^{*}$ & $85.5 \pm 1.1 \mathrm{~b}$ & $89.8 \pm 1.1 \mathrm{ab}$ & $88.8 \pm 1.4 \mathrm{a}$ & $89.0 \pm 1.6 \mathrm{a}$ & $86.0 \pm 1.2 \mathrm{a}$ \\
Chlorpyrifos/lufenuron & $83.5 \pm 1.8 \mathrm{bc}$ & $84.5 \pm 1.1 \mathrm{~d}$ & $85.0 \pm 1.7 \mathrm{~b}$ & $83.8 \pm 1.5 \mathrm{~b}$ & $80.3 \pm 1.1 \mathrm{~cd}$ \\
Spinetoram/lufenuron & $91.0 \pm 2.5 \mathrm{a}$ & $92.0 \pm 1.4 \mathrm{a}$ & $91.0 \pm 1.6 \mathrm{a}$ & $90.3 \pm 2.3 \mathrm{a}$ & $88.3 \pm 1.3 \mathrm{a}$ \\
Cypermethrin/lufenuron & $83.5 \pm 1.8 \mathrm{bc}$ & $84.5 \pm 1.9 \mathrm{~d}$ & $80.8 \pm 1.9 \mathrm{c}$ & $79.3 \pm 1.3 \mathrm{c}$ & $78.3 \pm 1.5 \mathrm{~d}$ \\
\hline
\end{tabular}

${ }^{*}$ Lufenuron was used at the half field rate. Numbers within the same column with a letter in common are not significantly different according to analysis of variance (ANOVA) test (LSD at $\mathrm{P}<0.05)$.

Table 5. Activity of $S$. littoralis esterases of AbouElmatameer and Shoubrakeate field populations

\begin{tabular}{|c|c|c|c|}
\hline \multirow[t]{2}{*}{ Season } & \multicolumn{2}{|c|}{ Specific activity $(\Delta \mathrm{OD} / \mathrm{mg}$ protein $/ \mathrm{min} \pm \mathrm{SE}$} & \multirow{2}{*}{$\begin{array}{l}\text { AbouEImatamir / } \\
\text { Shobrakeate ratio }\end{array}$} \\
\hline & AbouElmatameer & Shobrakeate & \\
\hline 2013 & $0.38 \pm 0.01 \mathrm{a}$ & $0.19 \pm 0.01 \mathrm{~b}$ & 2.00 \\
\hline 2014 & $0.49 \pm 0.03 \mathrm{a}$ & $0.24 \pm 0.01 \mathrm{~b}$ & 2.05 \\
\hline
\end{tabular}

Numbers within a row with a letter in common are not significantly different according to analysis of variance (ANOVA) test (LSD at $\mathrm{P}<0.05$ ). 
Table 6. Activity of $S$. littoralis GST of AbouElmatameer and Shoubrakeate field populations

\begin{tabular}{llll}
\hline Season & \multicolumn{2}{l}{ Specific activity $(\boldsymbol{\mu m o l} / \mathbf{~ m g}$ protein $/ \mathbf{m i n} \pm \mathbf{S E}$} & $\begin{array}{l}\text { AbouElmatamir } / \\
\text { Shobrakeate ratio }\end{array}$ \\
\cline { 2 - 4 } & AbouElmatameer & Shobrakeate & 2.00 \\
\hline 2013 & $138.30 \pm 8.01 \mathrm{a}$ & $69.40 \pm 4.11 \mathrm{~b}$ & 1.94 \\
2014 & $160.40 \pm 6.03 \mathrm{a}$ & $82.60 \pm 3.01 \mathrm{~b}$ & \\
\hline Numbers within a row & with a letter in common are not significantly different according to analysis of variance (ANOVA) test \\
(LSD at $\mathrm{P}<0.05)$. &
\end{tabular}

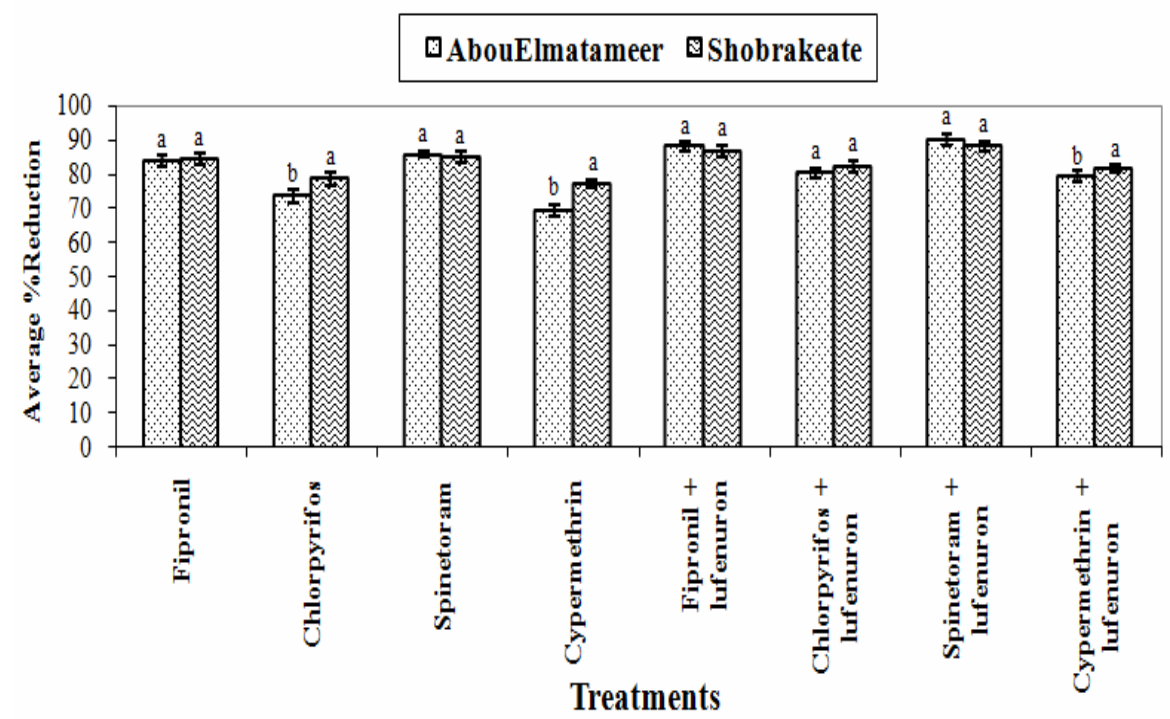

Fig. 1. Comparison between field performance of the insecticide treatments against CLW larvae at AbouElmatameer and Shobrakeate in 2013. Within the same column group, columns possessing the same letter do not differ significantly at $P=0.05$

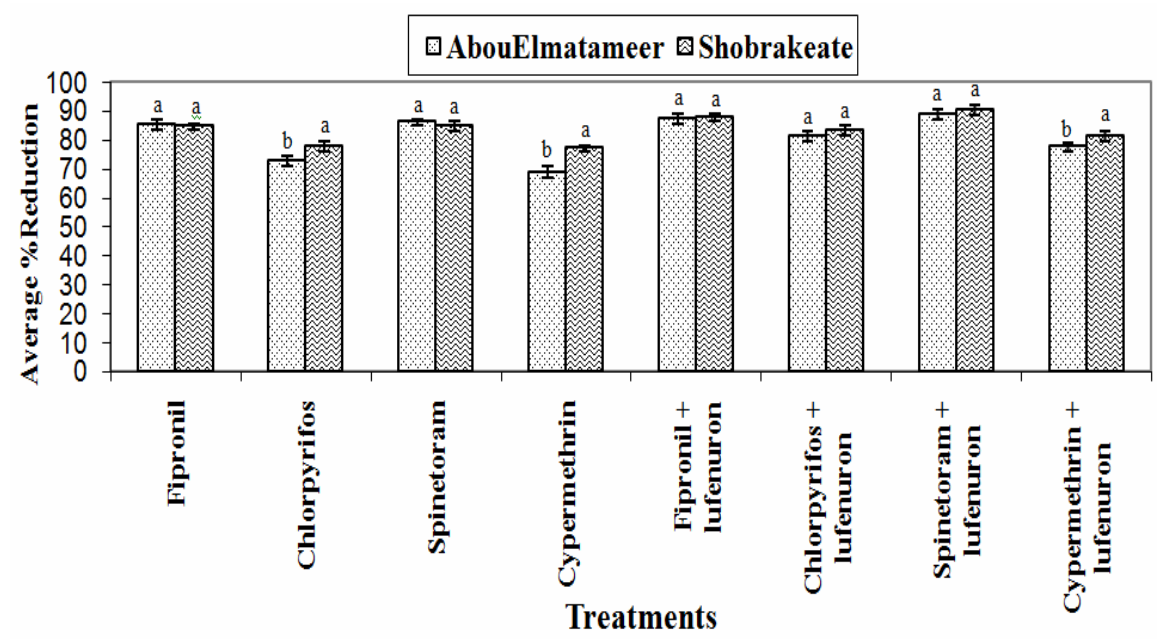

Fig. 2. Comparison between field performance of the insecticide treatments against CLW larvae at AbouElmatameer and Shobrakeate in 2014. Within the same column group, columns possessing the same letter do not differ significantly at $P=0.05$ 


\section{DISCUSSION}

Cotton leafworm is an economically important insect pest of cotton and vegetable crops. Management of this insect depends usually on insecticides especially organophosphate and pyrethroids. The extensive and unwise use of insecticides has resulted in development of resistance in CLW to these insecticide groups. In this study, existing solutions to the problem of resistance and strive to develop them further as tools towards effective resistance management were studied. Results indicated that, spinetoram and fipronil achieved significant higher CLW reduction percentages compared to chlorpyrifos and cypermethrin at both experimental locations AbouElmatameer and Shobrakeate. The impairment of chlorpyrifos and cypermethrin efficacy compared to spinetoram and fipronil, especially at AbouElmatameer, may be due to development of resistance in CLW to organophosphate and pyrethroid insecticide groups. Abo-Elghar et al., (2005) and Abou-Taleb (2010) recorded high levels of resistance against conventional insecticides like cypermethrin and chlorpyrifos by CLW in Egypt.

Cypermethrin, chlorpyrifos and cypermethrin / lufenuron (half field rate) mixture achieved significantly higher CLW reduction at Shobrakeate compared to at AbouElmatameer in both cotton seasons 2013 and 2014. This could be due to the variation in the dose, frequency and alternation of various insecticides in different localities for CLW control. In Egypt, many organophosphorus and synthetic pyrethroid insecticides have been used for CLW control, with appearance of resistance and cross resistance in many cases (EIGuindy et al., 1989; Abdallah, 1991; Rashwan et al., 1992). More recent, a significant intra-regional variation in susceptibility of different CLW populations has been reported in Nile Delta Egypt through 20022004 seasons (Abo-Elghar et al., 2005). Abou-Taleb (2010) also recorded differences in the susceptibility of CLW from different locations to chlorpyrifos and cypermethrin.

Metabolic resistance is one of the important insecticide resistance mechanisms. General esterases and glutathione $S$-transferases have been detected to cause a metabolic resistance in numerous insect pests (Hemingway, 2000; Chen et al., 2007). In this study, AbouElmatameer CLW strain showed significantly higher esterases and GST activities in 2013 and 2014 than that of Shobrakeate one, which is associated with a lower chlorpyrifos and cypermethrin field efficacy against CLW at AbouElmatameer compared to Shobrakeate. In previous studies, elevated esterases and GST activities are associated with organophosphate and pyrethroid resistance in CLW and other lepidopteran species (McCaffery, 1998; Attia, 1999; Abo Elghar et al., 2005; Abou-Taleb, 2010). Also, Yu et al., (2003) reported that, detoxification enzyme activities of microsomal oxidases, GST, and hydrolases were higher in field strains of Spodoptera frugiperda (has high resistance levels to carbamate, organophosphate and pyrethroid insecticides) than in the susceptible strain.

Insecticide mixtures are one of the proposed solutions of insecticide resistance. Our data showed that, mixing the half field rate of lufenuron with the tested insecticides especially chlorpyrifos and cypermethrin increased the field performance against CLW. In other studies, mixtures of insect growth regulators with spinosad had resulted in potentiating effects on mosquitoes (Darriet and Corbel, 2006) and cotton leafworm (El-Guindy et al., 1983; Abdel Rahman and Abou-Taleb, 2007). Also, in West Africa, the use of organophosphate and pyrethroid mixtures for cotton spraying has apparently prevented the development of pyrethroid resistance in populations of the Helicoverpa armigera for more than 20 years (Martin et al., 2003).

Finally it can be concluded that, fipronil and spinetoram can be good alternatives and can be used in combinations with the IGR, lufenuron in CLW control. Fortunately, fipronil and spinetoram differ in their site of action in the insect nervous system from classical insecticides. Also, the improvement in effects which are resulting from insecticide mixtures with the lufenuron half field rate can allow an improvement of insect control process, a reduction in the used insecticide quantities and overcoming of insecticide resistance.

\section{REFERENCES}

Aajoud, A., P. Ravanel, and M. Tissut. 2003. Fipronil metabolism and dissipation in a simplified aquatic ecosystem. J. Agric. Food. Chem., 51: 1347-1352.

Abdallah, M.D. 1991. A general view ofthe resistance problem of cotton pests in Egypt. Resistant Pest Management, 3: 22-25.

Abdel Rahman, S.M., and H.K. Abou-Taleb. 2007. Joint toxic action of spinosad and spinetoram with certain IGR compounds against cotton leafworm. Alex. J. Agric. Res., 52: 45-51.

Abo-El-Ghar, G.E., Z.A. Elbermawy, A.G. Yousef, and H.K. Abd Elhady. 2005. Monitoring and characterization of insecticide resistance in the cotton leafworm, Spodoptera littoralis (Boisd.) (Lepidoptera: Noctuidae). J. AsiaPacific Entomol., 8: 397-410. 
Abo-Elghar, M.R., M.E. Nassar, M.R. Riskalla, and S.F. AbdEl-Ghafar. 1986. Rate of development of resistance and pattern of cross-resistance in fenvalerate and decamethrinresistant strains of Spodoptera littoralis. Agricultural Research Review, 61: 141-145.

Abou-Taleb, H.K. 2010. Differential toxicity of some insecticides against egg and larval stages of cotton leafworm and role of two detoxification enzymes. Alex. Sci. Exch. J., 31: 356 - 364.

Ahmad, M., M.A. Saleem, and A.H. Sayyed. 2008. Efficacy of insecticide mixtures against pyrethroid- and organophosphate-resistant populations of Spodoptera litura (Lepidoptera: Noctuidae). Pest Manag Sci., 65: 266-274.

Attia, M.A.M. 1999. Studies on pesticide resistance phenomenon. M.Sc Thesis, Faculty of Agriculture, University of Alexandria.

Bobe, A., C.M. Coste, and J.F. Cooper. 1997. Factors influencing the adsorption of fipronil in soils. J. Agric. Food. Chem., 45: 4861-4865.

Chen, M.H., Z.J. Han, X.F. Qiao, and M.J. Qu. 2007. Resistance mechanisms and associated mutations in acetylcholinesterase genes in Sitobion avenae (Fabricius). Pestic Biochem Physiol., 87:189-195.

Cole, L.M., R.A. Nicholson, and J. E. Casida. 1993. Action of phenylpyrazole insecticides at the GABA-gated chloride channel. Pestic. Biochem. Phys., 46: 47-54.

Curtis, C.F. 1985. Theoretical models of the use of insecticide mixtures for management of resistance. Bull. Entomol., Res. 75, 259-265.

Darriet, F., and V. Corbel. 2006. Laboratory evaluation of pyriproxyfen and spinosad, alone and in combination, against Aedes aegypti larvae. J. Med. Entomol., 43: 11901194.

EI-Guindy, M.A., M.E. Keddis, M.M. Abd-Elsattar, and Y.F. Ghoneim. 1989. Status of resistance in cotton leafworm, Spodoptera littoralis (Boisd.) under the present Egyptian cotton pest control programme. Proc. 1st Int. Conf. Econ. Entomol., 2: 453- 462.

El-Guindy, M.A., A.M. El-Refai, and M.M. Abdel-Sattar. 198. The joint action of mixtures of insecticides, or of insect growth regulators and insecticides, on susceptible and diflubenzuron-resistant strains of Spodoptera littoralis Boisd. J. Pestic. Sci., 14: 246-252.

Gant, D.B., A.E. Chalmers, M.A. Wolff, H.B. Hoffman, and D.F. Bushey. 1998. Fipronil: action at the GABA receptor. Rev. Toxicol. 2: 147-156.

Hainzl, D., and J.E. Casida. 1996. Fipronil insecticide: novel photochemical desulfinylation with retention of neurotoxicity. Proc. Natl. Acad. Sci., 93: 12764-12767.

Hemingway, J. 2000. The molecular basis of two contrasting metabolic mechanisms of insecticide resistance. Insect Biochem Mol Biol., 30:1009-1015.
Henderson, C.F., and E.W. Telton. 1955. Tests with acaricides against the brown wheat mite. J. Econ. Entomol., 48, 157161.

Insecticide evaluation protocol. 2013. Egyptian Ministry of Agriculture, pp. 24.

Issa, Y.H., M.E. Keddis, M.A. Abdel-Sattar, F.A. Ayad, and M.A. El-Guindy. 1984a. Survey of resistance to organophosphorus insecticides in field strains of the cotton leafworm during 1980-1984 cotton-growing seasons. Bulletin of the Entomological Society of Egypt, Economic Series, 14: 399-404.

Issa, Y.H., M.E. Keddis, M.A. Abdel-Sattar, F.A. Ayad, and M.A. El-Guindy. 1984b. Survey of resistance to pyrethroids in field strains of the cotton leafworm during 1980-1984 cotton-growing seasons. Bulletin of the Entomological Society of Egypt, Economic Series. 14: 405-411.

Kao, C.H., C.F. Hung, and C.N. Sun. 1989. Parathion and methyl parathion resistance in diamondback moth (Lepidoptera: Plutellidae) larvae. J. Econ. Entomol., 82: 1299-1304.

Lowry, O.H., N.J. Rosenbourgh, R.J. Farr, and A. L. Rondall. 1951. Protein measurement with folin phenol reagent. J. Biol. Chem., 193: 265-275.

Martin, T., O.G. Ochou, M. Vaissayre, and D. Fournier. 2003. Oxidases responsible for resistance to pyrethroids sensitize Helicoverpa armigera (Hubner) to triazophos in West Africa. Insect Biochem. Mol. Biol., 33:883-887.

McCaffery, A.R. 1998. Resistance to insecticides in Heliothine Lepidoptera: A global view. Phil. Trans. R Soc., 353: 1735-1750.

Moffat, A.S. 1993. New chemicals to outwit insect pests. Science, 261: 550-551.

Rashwan, M.B., Z.A. EI-Bermawy, A.A. El-Shiekh, and H.S.A. Radwan. 1992. The onset of organophosphates and carbamates resistance among Lower Egypt population of the cotton leafworm, Spodoptera littoralis. Bull. Ent. Soc. Egypt, Econ. Ser., 19: 211-220.

Roush, R.T. 1993. Occurrence, genetics and management of insecticide resistance. Parasitol. Today, 9: 174-179.

SAS Institute, Inc. (1999). PC-SAS users guide, Version 8. North Carolina statistical analysis system Institute, Inc.

Van Asperen, K. 1962. A study of housefly esterases by means of a sensitive colorimetric method. J. Insect Physiol., 8: 401-416.

Yu, S.J., S.N. Nguyen, and G.E. Abo-Elghar. 2003. Biochemical characteristics of insecticide resistance in the fall armyworm, Spodoptera frugiperda (J.E. Smith). Pesticide Biochemistry and Physiology, 77: 1-11. 


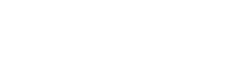

كماءة الفيبرونل وصضن المعاللات الأخرى بالمبيدات ضند دوة ورق الفالن ودور إنزيملت إزالة اللمبة

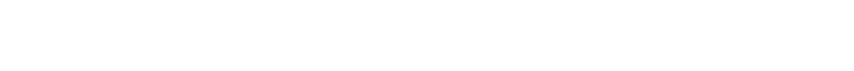

الكلوربيريفوس، اللسيبرميثرن، الفيبرونل و الإبيبينيتورلم

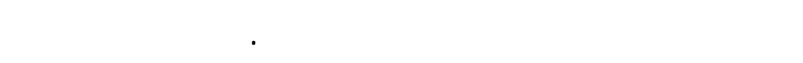

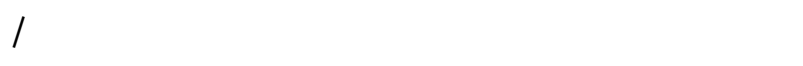

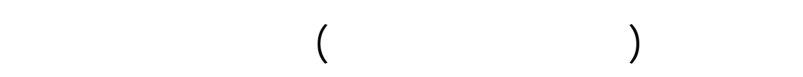

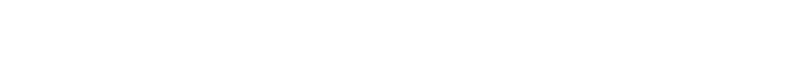

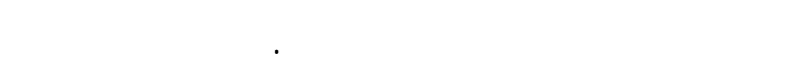

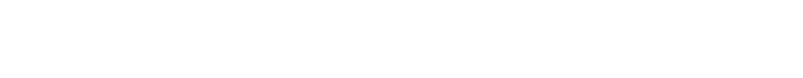

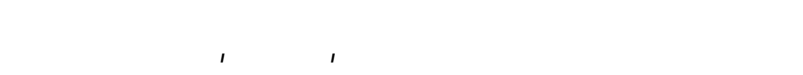

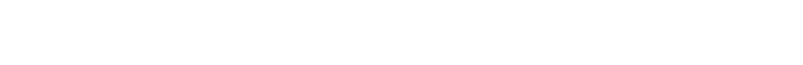

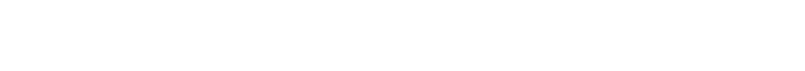

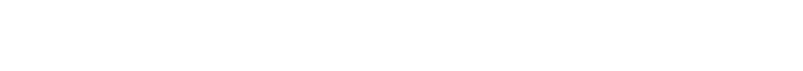

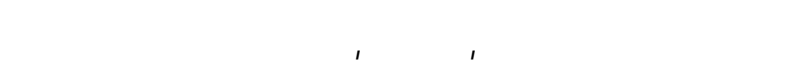

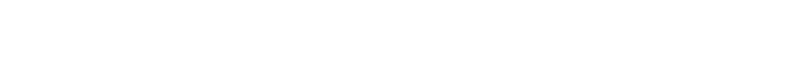

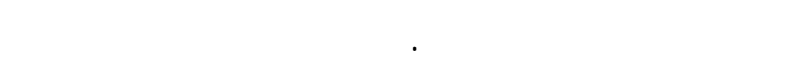

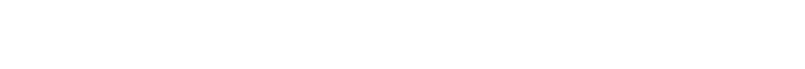

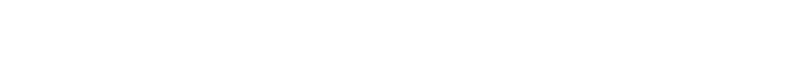

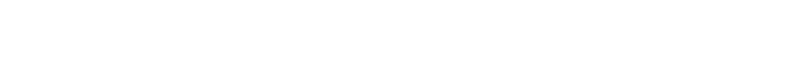

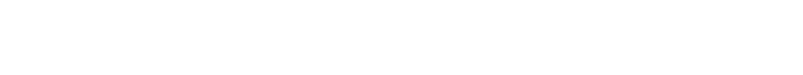
اللوفينيورون(بنصف الجرعة الققلية) مع المبيدات المختبرة يجنس من نتائج المكافحة ويقل من مقاومة اليرقلت للمبيدات.
لجريت الدرلسات الحقلية بموقعين مختلفن(أبو

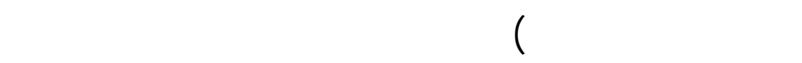

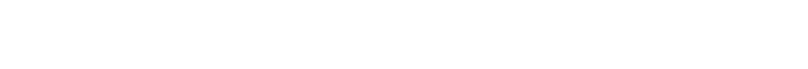

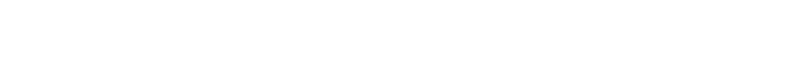
ترلنفيريز و الإستيريز لدودة ورق الفطن بكلا الموقعين.

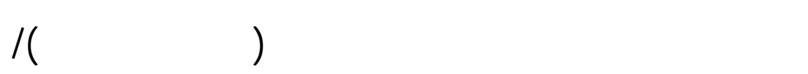

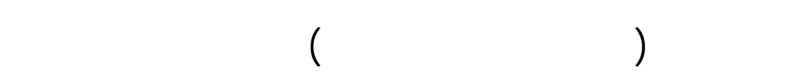

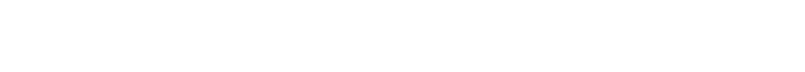

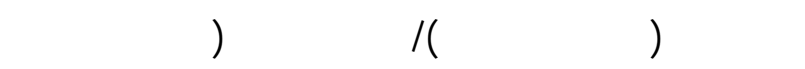

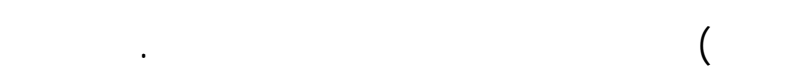

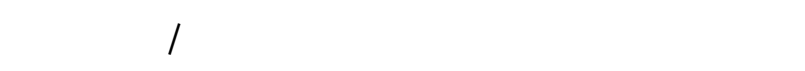

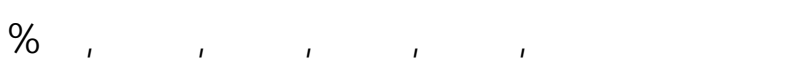

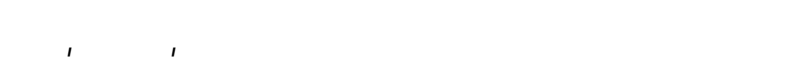
فترا

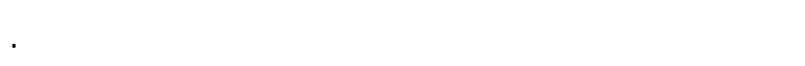

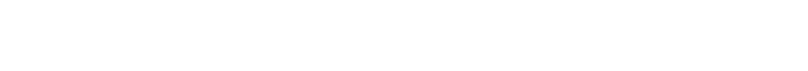

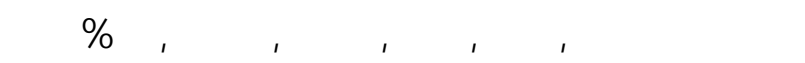

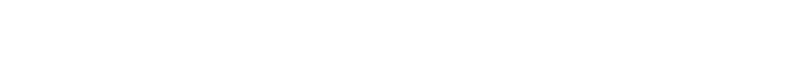

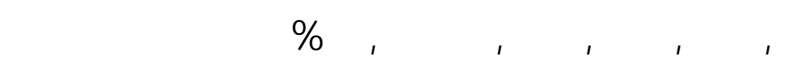
على التواله. كما أوضصت نتائج المعلملة بلمالسيبرميثرن

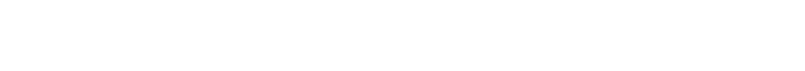

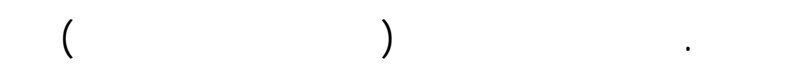

